\title{
THE CORRELATION BETWEEN TRANSFORMATIONAL LEADERSHIP STYLE AND ORGANIZATIONAL CULTURE WITH PERFORMANCE OF SESPIMMA POLRI'S PERSONNEL IN JAKARTA
}

\author{
Charles Bohlen Purba and Supangat \\ Bhayangkara Jakarta Raya University \\ e-mail :bohlenpurba@yahoo.com
}

\begin{abstract}
The purpose of this study is to analyze, test and determine: 1)The correlation between transformational leadership style with the Performance of SESPIMMA POLRI's Personnel in Jakarta. 2) The correlation between the organizational culture with the Performance of SESPIMMA POLRI's Personnel in Jakarta. 3) Relationship between both Transformational Leadership style and Organizational Culture with the Performance of SESPIMMA POLRI's Personnel in Jakarta. This research was conducted in South Jakarta area SESPIMMA Police Agency with the address of Jalan Ciputat Raya No. 40 Kebayoran Lama. The samples were gathered using the Slovin formula, then out of a total population of 131 people obtained a sample of 99 people. Data analysis was performed with SPSS versi17.0. Results of analysis can be concluded as follows: 1) There is a positive correlation between transformational leadership style with the Performance of SESPIMMA POLRI's Personnel in Jakarta, it can be determined by the calculation of the $t$ test where th>tt. Based on the calculation of product moment formula which, rh> rt. This means that the variations performed by SESPIMMA POLRI's Personnel (Variable Y) are determined by transformational leadership (X1 variable). 2) There is a positive relationship between the organizational culture and the performance of SESPIMMA Police personnel, it can be determined by the calculation of the $t$ test where th>tt. And based on the calculation of product moment formula which, rh> rt. This means that the variations performed by SESPIMMA POLRI's Personnel (Variable Y) are determined by the Cultural Organization (Variable X2). 3) There is a positive relationship between Transformational Leadership and Organizational Culture with the performance of SESPIMMA POLRI's personnel, it can be determined by the calculation of the F test where $\mathrm{Fh}>\mathrm{Ft}$. And based on the calculation of product moment it is known that $\mathrm{rh}>\mathrm{rt}$. This means that $48.9 \%$ of the variation Variable Y (Performance of SESPIMMA's Police Personnel) is determined by the Transformational Leadership (Variable X1) and Cultural Organization (Variable X2).
\end{abstract}

Keywords: Transformational Leadership, Organizational Culture, Performance

\begin{abstract}
Abstrak: Tujuan dari penelitian ini adalah untuk menganalisis, menguji dan menentukan: 1) Korelasi antara gaya kepemimpinan transformasional dengan Kinerja SESPIMMA POLRI Personil di Jakarta. 2) Korelasi antara budaya organisasi dengan kinerja dari SESPIMMA POLRI Personil di Jakarta. 3) Hubungan antara kedua gaya kepemimpinan transformasional dan Budaya Organisasi dengan Kinerja SESPIMMA POLRI Personil di Jakarta. Penelitian ini dilakukan di daerah Jakarta Selatan Badan Kepolisian SESPIMMA dengan alamat Jalan Ciputat Raya No. 40 Kebayoran Lama. Sampel dikumpulkan dengan menggunakan rumus Slovin, maka dari total populasi 131 orang diperoleh sampel sebanyak 99 orang. Analisis data dilakukan dengan SPSS versi17.0. Hasil analisis dapat
\end{abstract}


disimpulkan sebagai berikut: 1) Ada korelasi positif antara gaya kepemimpinan transformasional dengan Kinerja SESPIMMA POLRI Personil di Jakarta, dapat ditentukan oleh perhitungan uji $\mathrm{t}$ di mana th> tt. Berdasarkan perhitungan formula product moment yang, rh> rt. Ini berarti bahwa variasi yang dilakukan oleh SESPIMMA POLRI Personil (Variabel Y) ditentukan oleh kepemimpinan transformasional (variabel X1). 2) Ada hubungan positif antara budaya organisasi dan kinerja personil Polisi SESPIMMA, dapat ditentukan oleh perhitungan uji $\mathrm{t}$ di mana th> tt. Dan berdasarkan perhitungan formula product moment yang, rh> rt. Ini berarti bahwa variasi yang dilakukan oleh SESPIMMA POLRI Personil (Variabel Y) ditentukan oleh Organisasi Budaya (Variable X2). 3) Ada hubungan positif antara Kepemimpinan Transformasional dan Budaya Organisasi dengan kinerja personil SESPIMMA POLRI, dapat ditentukan oleh perhitungan uji $\mathrm{F}$ dimana $\mathrm{Fh}>$ Ft. Dan berdasarkan perhitungan product moment diketahui bahwa rh> rt. Ini berarti bahwa 48,9\% dari variasi Variabel Y (Kinerja SESPIMMA Kepolisian Personil) ditentukan oleh Kepemimpinan Transformasional (Variable X1) dan Budaya (Variable $\mathrm{X} 2)$.

Kata kunci: Kepemimpinan Transformasional, Budaya Organisasi, Kinerja

\section{INTRODUCTION}

It is observed that there are still many lecturer who have not been able to show a high performance in their lectures despite being regarded as professional lecturer. This was proven by many professional lecturers are still categorized as pedagogic, a certified lecturers whom are not able to properly guide, teach, and gives learning models and strategies in their lecture so that the students are still experience some difficulties in receiving the materials given by the lecturer.

In the execution of their duties, SESPIMMA POLRI's personnel in Jakarta need to pay attention to the good communication and their relationship between their personnel and leaders, their personnel and colleagues, and between their personnel student officers. Good relationship and communication intertwining a good interaction between personnel of SESPIMMA POLRI in Jakarta. Any activities performed will be a successful if there is a good relation and a good communication between student officers as the instructed component. Personnel's performance will increase as there are healthy relationship and communication between components of SESPIMMA POLRI in Jakarta because with good and structured relationship and communication pattern, it will push any individual to do their best in finishing their tasks.

In the condition if personnel are lacking the required ability, especially, Gadik is a person who doesn't fully understands instructional strategies and has a poor classroom management, thus causing inability in planning the implementation of learning in the classroom, where Gadik still fixated on the old paradigm that is too focused on Gadik, so the officer students are less actively involved in the learning process.

The things mentioned above will certainly be reflected in personnel's performance within the environment of SESPIMMA POLRI in Jakarta which shows a significant shift to a more positive direction. And also the leadership and organizational culture which are not supportive to the learning process that orientates to the increasing quality of student officers. The current organizational culture has not been able to create any organizational culture or any quality in the work life that gives the opportunity of self-development, and 
prosperity that could covers the basic needs of Gadik. So, it would increase the performance of personnel.

The condition that occurred in this field is a concrete example of the lack of personnel's performance which is lower than what was expected. This of course can be an obstacle in improving personnel's performance.

Organizational culture often faced with a problem in the learning device fabrication techniques. The Gadik are used to make their learning material by copying exactly the same as previous years. Even today with the ease of Internet access, the Educators/lecturers are often just simply download them from the Internet to set up a learning material. Thus it seems as if that they didn't put any thought when making their learning material, or when evaluating any learning process, or even when they are trying to guide their students.

Individual with transformational leadership style in them could be seen from the way they do their job and how they take responsibility that of course, reflected in SESPIMMA POLRI's performance in Jakarta. The lack of readiness and the ability of a Gadik in executing their tasks and responsibilities is because every lecturer has their own way of interpreting and understanding the tasks and responsibilities. The above clarification would be very interesting to studied scientifically, so, the writer will conduct a research about Personnel's Performance with the Transformational Leadership Style and Organizational Culture by taking the title of "The Correlation between Transformational Leadership and Organizational Culture with the Performance of SESPIMMA POLRI's Personnel in Jakarta".

\section{RESEARCH METHOD}

The research could be defined as a way to solve a problem by using a particular scientific method, theory, design, and conduct it systematically. This research is a quantitative research as what Sugiyono (2008:7) disclosed, quantitative method is scientific method because it has all the scientific principles which are, concrete / empirical, objective, measurable, rational and systematic. Beside, this research could be classified in to a quantitative research, because the data that required are the data in the form of numerical or data in the form of informations, comments, opinion or statements that later will be modified in to quantitative form (will be change in to numbers). The numerical figures were then processed using a statistical formula, and will be interpreted in order to test the hypotheses that have been proposed. In line with that expressed by Sugiyono (2008:8), this method is called quantitative methods for research data are in the form of numerical figures and use statistical analysis.

\section{DISCUSSION OF RESEARCH OUTCOME}

Based on the results of the analysis, it can be concluded that the characteristic of each variable. The characteristics of each variable are stated in the following:

Correlation of X1 (Transformational Leadership) with Y (The Performance of SESPIMMA POLRI's Personnel) . According to the simple linier regression analysis, with the Transformational Leadership (X1) and the Performance of SESPIMMA POLRI's personnel (Y) as the pair of data, it generates a regression of coefficient value of 0,522 and 
constant value of 61,709 . Therefore, the correlation between the variable of Transformational Leadership (X1) and the Performance of SESPIMMA POLRI's personnel (Y) have the following equations of, $\mathrm{Y}=61,709+0,522 \mathrm{X} 1$.

Based on the test results of the above statistics, it could be seen that the hypothetic correlation between Transformational Leadership with the Performance of SESPIMMA POLRI's personnel is acceptable, it can be determined by the calculation of the test where $t_{h}>t_{t}(7,746>1,67)$. And based on the equation of the product correlation moment of efficiency, it is known; at $\alpha=0,05$ that the $r_{h}>r_{t}(0,618>0,202)$, which means that there is a positive correlation between Transformational Leadership with the Performance of SESPIMMA POLRI's personnel, with the determination of efficiency of $r^{2}{ }_{13}=0,382$. This means that $38,2 \%$ of variation in SESPIMMA POLRI personnel's performance (Y) is influenced by Transformational Leadership (X1).

Correlation of X2 (Organizational Culture) with Y (the Performance of SESPIMMA

POLRI's Personnel). According to the simple linier regression analysis, with the $\mathrm{X} 2$ (Organizational Culture) and Y (the Performance of SESPIMMA POLRI's Personnel), it generates a regression of coefficient value of 0,672 and constant value of 47,383. Therefore, the correlation between the variable of Transformational Leadership (X1) with the Performance of SESPIMMA POLRI's personnel (Y) have the following equations of, $\mathrm{Y}=47,383+0,672 \mathrm{X} 1$.

Based on the test results of the above statistics, it could be seen that the hypothetic correlation between Organizational Culture with the Performance of SESPIMMA POLRI's personnel is acceptable, it can be determined by the calculation of the test where $t_{h}>t_{t}(8,609>1,67)$. And based on the equation of the product correlation moment of efficiency, it is known; at $\alpha=0,05$ that the $r_{h}>r_{t}(0,658>0,202)$, which means that there is a positive correlation between Transformational Leadership with the Performance of SESPIMMA POLRI's personnel, with the determination of efficiency of $\mathrm{r}^{2}{ }_{13}=0,433$. This means that $43,3 \%$ of variation in SESPIMMA POLRI personnel's performance (Y) is influenced by Organizational Culture (X2).

Correlation between X1 (Transformational Leadership) and X2 (Organizational Culture) with Y (The Performance of SESPIMMA POLRI's Personnel). According to the double regression linier analysis research data, between X1 (Transformational Leader) and X2 (Organizational Culture), it generates a regression of coefficient value of 0,269 and 0,451 , also a constant value of 37,730. Therefore, the correlation between the variable of Transformational Leadership (X1) and the Organizational Culture (X2) with the Performance of SESPIMMA POLRI's personnel (Y) have the following equations of, $\hat{Y}=$ $37,730+0,269 \mathrm{X} 1+0,451 \mathrm{X} 2$.

Based on the test results of the above statistics, it could be seen that the hypothetic correlation between Transformational Leadership and Organizational Culture with the Performance of SESPIMMA POLRI's personnel is acceptable, it can be determined by the calculation of the $F$ test where $F_{h}>F_{t}(45,844>3,10)$. And based on the equation of the product correlation moment of efficiency, it is known; $r_{h}>r_{t}(0,699>0,202)$, which means at $\alpha=0,05$, there is a positive correlation between Transformational Leadership and Organizational Culture with the determination of efficiency of $r^{2}{ }_{12}=0,489$. This means that $48,9 \%$ of variation in SESPIMMA POLRI personnel's performance (Y) are influenced by Transformational Leadership (X1) and Organizational Culture (X2). 


\section{CONCLUSION}

There is a positive correlation between Transformational Leadership with the Performance of SESPIMMA POLRI's personnel, it can be determined by the calculation of the $t$ test where $t_{h}>t_{t}(7,746>1,67)$. And based on the equation of the product correlation moment of efficiency, it is known; at $\alpha=0,05$ that the $r_{h}>r_{t}(0,658>0,202)$, which means that there is a positive correlation between Transformational Leadership with the Performance of SESPIMMA POLRI's personnel, with the determination of efficiency of $r^{2}{ }_{13}=0,382$. This means that $38,2 \%$ of variation in SESPIMMA POLRI personnel's performance (Variable Y) is influenced by Transformational Leadership (Variable X1).

There is a positive correlation between Organizational Culture with the Performance of SESPIMMA POLRI's personnel, it can be determined by the calculation of the $t_{\text {test }} t_{h}$ $>t_{t}(8,609>1,67)$. And based on the equation of the product correlation moment of efficiency, it is known; at $\alpha=0,05$ that the $r_{h}>r_{t}(0,658>0,202)$, which means that there is a positive correlation between Transformational Leadership with the Performance of SESPIMMA POLRI's personnel, with the determination of efficiency of $\mathrm{r}^{2}{ }_{13}=0,382$. This means that $38,2 \%$ of variation in SESPIMMA POLRI personnel's performance (Variable $\mathrm{Y}$ ) is influenced by Organizational Culture (Variable X2).

There is a positive correlation between Transformational Leadership and Organizational Culture with the Performance of SESPIMMA POLRI's personnel, it can be determined by the calculation of the $F$ test where $F_{h}>F_{t}(45,844>3,10)$. And based on the equation of the product correlation moment of efficiency, it is known; at $\alpha=0,05$ that the $r_{h}>r_{t}(0,658>0,202)$, which means at $\alpha=0,05$, there is a positive correlation between Transformational Leadership and Organizational Culture with the determination of efficiency of $\mathrm{r}_{12}^{2}=0,489$. This means that $48,9 \%$ of variation in SESPIMMA POLRI personnel's performance (Variable Y) are influenced by Transformational Leadership (Variable X1) and Organizational Culture (Variable X2).

\section{SUGGESTIONS}

The performance of SESPIMMA POLRI's personnel in Jakarta should be improved, through coaching and training or implementation of policies that will lead to the emergence of intrinsic and extrinsic motivation of SESPIMMA POLRI's personnel. Related to the improvement of the performance from SESPIMMA POLRI personnel practically could be improved through the desire of work, urge to achieve, change in working behavior, executing the duties, responsibilities in the assigned job, interpersonal relationship in SESPIMMA POLRI's personnel, leader's supervision, salary/honorarium, the environment and the policies.

The transformational leadership in SESPIMMA POLRI's personnel should be improved, through a leadership development program. For the leaders to understand more about their role and duties as the chairman. Practically, Related to the improvement of the Transformational Leadership, it should be improved through the leader's role such as, arrangement of SESPIMMA POLRI's program, innovating motivations, directing and guiding the subordinates, and executing their duties. The abilities like, measuring any work, building a relation, problem solving, influence others, making decision for 
themselves, participatory and democratic are very essential in order for any taken decisions would support the objectives.

The organizational culture of SESPIMMA POLRI's personnel in Jakarta should be improved, through the mobilization and participation of the resources in the environment of SESPIMMA, elderly people, or surround citizen so that the organizational culture would be established properly. Regarding the improvement in organizational culture, it can be improved through trust, supportive attitude, openness which will lead to a mutual understanding, respectful attitude, and mutually develop each other quality. A better environment in SESPIMMA, such as, the communication system, cooperation in finishing tasks, mutual trust, appreciation with creativity and innovation, working environment, a better implementation in management system like in the SESPIMMA organizational structure, delegation of authority, decision making, transparency in SESPIMMA's bureaucracy system which is open to critics and accepts opinion for the improvement of SESPIMMA.

\section{BIBLIOGRAPHY}

Arikunto, Suharsimi. (2013) Prosedur Penelitian, Suatu Pendekatan Praktik. Jakarta: Rineka Cipta. . (2012) Dasar-dasar Evaluasi Pendidikan Edisi 2. Jakarta: Bumi Aksara.

Arthor S. Reber dan Emily S. Reber, (2010) Kamus Psikologi. Yogyakarta: Pustaka Pelajar.

As’ad, Moh. (2015) Psikologi Industri, Edisi Keempat, Yogyakarta: Liberty.

Bangda, Tim Bantek. (2013) Bantuan Teknik Penguatan Kinerja TPM, Jakarta: Depdagri

Baron, Robert A., (2012) Psychology. Boston: Allyn and Bacon.

Berger, Lance A. \&Dorothy R., Berger. (2007) The Hand Book of Best Practices onTalent Management - Mengidentifikasi, Mengembngkan dan Mempromosikan Orang Terbaik untuk Menciptakan Keunggulan Organisasi, Cetakan 1, Jakarta: PPM.

Bernadin, H. J. and Russell, J., E. A., (2013) Human Resource Management. New York: Mc. Graw Hiil., Inc.

Borich, Gary D. dan L. Tombary, Martin, (2015) Educational Psychology: A Contemporary Approach. New York: Harper Collins College Publishers.

Chatab, Nevizond, (2014) Profil Budaya Organisasi. Jakarta: Alfabeta.

Danim, Sudarwan dan Suparno. (2008) Manajemen dan Kepemimpinan Transformasional Kepala Sekolah. Jakarta: Rineka Cipta.

Davis \& Newton, (2008) Perilaku Dalam Organisasi Edisi 7. Jakarta: Erlangga

Feldman, Robert S., (2016) Undesrtanding Psychology. New York: The McGraw-Hill Companies Inc.

Harrell, Keith. (2008) Attitude is everything, terjemahan oleh Andry Kristiawan. Jakarta: PT. Gramedia Pustaka Utama.

http://www. accel-team. com/motivation/theory_01. html

Jhon Paine, Philip Turner, Robert Pryke, (2012) Total Quality and Education. Brisbane: Ashton Scholastic Pry Limited.

Lunenburg, Irby. (2006) The principalshi: Vision to Action. Wadsworth: Cengage Learning.

Lussier, Robert N., (2008) Human Relations Organizations. New York: Mc. Graw-Hill Irwin. 
Mangkunegara, (2015) Perilaku dan Budaya Organisasi. Jakarta: Refika-Aditama.

Mangkuprawira dan Hubies, (2007) Manajemen mutu Sumber Daya Manusia. Jakarta: Ghalia Indonesia.

Mathis, Robert L. \& Jackson, John H., (2006) Human Resource Management. Jakarta: Salemba Empat

Morrison, Terrence. (2011) Actionable Learning: A Handbook for Capacity Buliding Trough Case Based Learning. Asian Development Bank Institute.

Najati, Usman, (2009) Al-Qur'an dan Ilmu Jiwa, terj. Ahmad Rofi Usmani. Bandung: PustakaSetia.

Nawawi, Hadari dan Hadari M. Martini, (2014) Kepemimpinan yang Efektif. Yogyakarta: Gajah Mada Unbiversity Press

Owen, Robert G., (2011) Organizational Behaviour In Education. Boston:Allyn and Bacon.

Priansa, Donni Juni. (2014) Kinerja dan Profesionalisme Guru, Bandung: Alfabeta.

Pudjosumedi, AS. (2010) Organisasi dan Kepemimpinan. Jakarta: Uhamka Press.

Razik, A. Taher \& D. Austin Swanson. (2005) Fundamental Concep of Educational Leadershipand Management. New Jersey: Englewood Kongan Page Limited.

R. Terry, George \& Rue, Leslie W., (2013) Dasar-dasar Manajemen (terjemahan), Jakarta: Bumi Aksara.

Rivai, Veitzal. (2014) Manajemen Sumber Daya untuk Perusahaan dari Teori Ke Praktek, Jakarta: Rajawali Pers.

Robbins, Stephen P, (2016) Perilaku Organisasi: Konsep, Kontroversi, Aplikasi penerjemah Hadyatma Pujaatmaka. Jakarta: Prenhalindo, Jilid I. , (2014) Essentials of Organization Behavior. Englewood Cliffs, New Jersey: Prentice-Hall.

, (2008) Organizational Behavior: Concept, Controversies and Applications. New York: Prentice Hall International Inc.

, (2006) Perilaku Organisasi, penerjemah Benyamin Mola. Jakarta: PT Indeks, Edisi ke-10.

, (2003) Organizational Behaviour. New Jersey: Pearson Educatiion. Inc.

Robbins, Stephen P. and Judge, Timothy A, 2009. Organizational Behavior. New Jersey: PearsonEducation, Inc.

Santoso, Gempur. (2015) FundamentalMetodelogi Penelitian Kuantitatif dan Kualitatif. Jakarta: Prestasi Pustaka Publishers.

Sarwoto, (2015) Dasar-dasar Organisasi dan Manajemen. Jakarta: Ghalia Indonesia.

Sedarmayanti. (2007) Manajemen SDM. Bandung, PT. Refika Aditama. h. 51.

Slavin, Robert E., (2011) Educational Psychology: Theory and Practice. New Jersey: Prentice Hall Inc.

Sobirin, Achmad, (2007) Budaya Organisasi: Pengertian, Makna dan Aplikasinya dalam kehidupan Organisasi. Yogyakarta: UPP STIM YKPN.

Soecipto \& Rahflis Kosasi, Profesi Keguruan, Jakarta: PPPMTK Dikti Depdikbud.

Steers, Richard M. dan Porter, Lyman W., (2011) Motivation and Work Behavior. New York: McGraw-Hill.

Steers, Richard M., (2008) Organizational Behavior. Boston: Scott, Foreman and Company. 
Sternberg, Robert J., (2011) Review of Working with Emotional Intelligence, (http://eqi. org/busi. htm)

Sudaryono, (2014) Budaya \& Perilaku Organisasi. Jakarta: Lentera Ilmu Cendekia.

Sugiyono, (2008) Metode Penelitian Kuantitatif Kualitatif dan $R \& D$. Bandung: Alfabeta

Suhendi, Hendi dan Anggara, Sahya. (2010) Perilaku Organisasi. Bandung: Pustaka Setia.

Supardi. (2013) Kinerja Guru. Jakarta: Raja Grafindo Persada.

Sutarto, (2015) Dasar-dasar Organisasi. Jogjakarta: Gajah Mada University Press,

Syaraf, M. Jalal dan Astawi, Abdul Rahman Muhammad, (1972) Psycology Al-Hayah AlRuhiyah Fil Masikhiyah Wal Islam. Iskandariyah: Mansya' ah Al Ma'arif.

Uno, Hamzah B. dan Lamatenggo, Nina. (2014) Teori Kinerja dan Pengukurannya. Jakarta: Bumi Aksara.

Wahab, Abdul Aziz, (2008) Anatomi Organisasi dan Kepemimpinan Pendidikan, Bandung: Alfabeta.

Wagner III, John A. dan John R, Hollenbeck. (2005) Management of Organizational Behaviour. New Jersey: Prentice-Hall. Inc.

Wayne K., Hoy and Cecil G. Miskel, (2001) Educational Administration: Theory, Research, and Practice Sixth Edition, New York: McGraw Hill co.

Whitmore, John. (2007) Coaching For Performance, Seni Mengarahkan untuk Mendongkrak Kinerja, Terj. Dwi Helly Purnomo dan Louis Novianto. Jakarta: Gramedia Pustaka Utama.

Wibowo, (2011) Budaya Organisasi: Sebuah Kebutuhan untuk Meningkatkan Kinerja Jangka Panjang. Jakarta: Grafindo.

Wibowo, (2013) Manajemen Kinerja, Edisi Keempat, Jakarta: Raja Grafindo Persada.

Wibowo, (2014) Perilaku dalam Organisasi. Jakarta: Raja Grafindo Persada.

Winarsunu, (2010) Statistik dalam Penelitian Psikologi dan Pendidikan. Malang: UMM Press.

Yukl, Gary A. (2009) Kepemimpinan dalam Organisasi. terjemahan Tri Wibowo, Jakarta: Indeks. 